\title{
INFLUENCE OF LEADERSHIP, ORGANIZATIONAL CLIMATE AND JOB SATISFACTION ON TEACHER PERFORMANCE
}

\author{
Dedi Suhendro $^{1 *}$, Ilham Syahputra Saragih ${ }^{2}$ \\ ${ }^{1}$ AMIK Tunas Bangsa Pematangsiantar Sumatera Utara \\ dedi.su@amiktunasbangsa.ac.id \\ ${ }^{2}$ STIKOM Tunas Bangsa Pematangsiantar Sumatera Utara \\ ilham@amiktunasbangsa.ac.id
}

\begin{abstract}
The purpose of this study was to determine the Influence of leadership on the performance of teachers in the State-Owned High School I Tanah Jawa, Simalungun Regency. To find out the influence of organizational climate on the performance of teachers in the State-Owned High School I Tanah Jawa, Simalungun Regency. To determine the Influence of job satisfaction on teacher performance in the State-Owned High School I Tanah Jawa, Simalungun Regency. To find out the influence of leadership, organizational climate and job satisfaction on the performance of teachers in the State-Owned High School I Tanah Jawa, Simalungun Regency. The sample in this research amounted to 55 teachers. Data analysis techniques in this research used descriptive analysis and multiple linear regression analysis. The results of this research explain that the leadership variable has a positive and significant Influence on teacher performance by $33.27 \%$. Organizational climate variables have a positive and significant Influence on teacher performance by $43.30 \%$. Job satisfaction variable has a positive and significant Influence on teacher performance $42.34 \%$. The variables of leadership, organizational climate and job satisfaction have a positive and significant Influence on teacher performance by $70.00 \%$, while the remaining $30.00 \%$ is influenced by other factors not examined.
\end{abstract}

Keywords: Leadership, Organizational Climate, Job Satisfaction, Teacher Performance.

\begin{abstract}
Abstrak
Tujuan dari penelitian ini adalah untuk mengetahui pengaruh Kepemimpinan terhadap Kinerja Guru di Sekolah Menengah Atas Negeri I Tanah Jawa Kabupaten Simalungun. Untuk mengetabui pengarub iklim organisasi terhadap kinerja guru di Sekolah Menengah Atas Negeri I Tanah Jawa Kabupaten Simalungun. Untuk mengetahui pengaruh Kepuasan Kerja terhadap Kinerja Guru di Sekolab Menengah Atas Negeri I Tanah Jawa Kabupaten Simalungun. Untuk mengetahui pengarub kepemimpinan, iklim organisasi dan kepuasan kerja terhadap kinerja guru di Sekolah Menengah Atas Negeri I Tanah Jawa Kabupaten Simalungun. Sampel dalam penelitian ini berjumlah 55 guru. Teknik analisis data dalam penelitian ini menggunakan analisis deskriptif dan analisis regresi linier berganda. Hasil penelitian menjelaskan bahwa variabel kepemimpinan berpengaruh positif dan signifikan terhadap kinerja guru sebesar 33,27\%. Variabel iklim organisasi berpengaruh positif dan signifikan terhadap kinerja guru sebesar 43,30\%. Variabel kepuasan kerja berpengaruh positif dan signifikan terhadap kinerja guru 42,34\%. Variabel kepemimpinan, iklim organisasi dan kepuasan kerja berpengaruh positif dan signifikan terhadap kinerja guru sebesar 70,00\%, sedangkan sisanya sebesar 30,00\% dipengarubi oleh faktor lain yang tidak diteliti.
\end{abstract}

Kata Kunci: Kepemimpinan, Iklim Organisasi, Kepuasan Kerja, Kinerja Guru. 


\section{INTRODUCTION}

Organizational structure defines how tasks are divided, grouped, and coordinated in organizations. Every organization has a structure that clarifies the roles that organizational members perform, so that everyone understands their responsibilities to the group. The structure of an organization tells you the character of an organization and the values it believes in. Understand the impact of leadership and leadership styles on job satisfaction and organizational success is very important when recruiting staff. The purpose of this study was to determine the Influence of leadership on the performance of teachers

The concept of transformational leadership is one of the most significant leadership models put forward in relation to the advancement of the educational field (Baptiste, 2019). Organizational climate is a set of characteristics that define an organization and differentiate that particular organization with other organizations (Suandi, Ismail, \& Othman, 2014). Job satisfaction is defined as the pleasurable emotional state resulting from the appraisal of one's job as achieving or facilitating the achievement of one's job values (Balyer et al., 2017). Phenomena that occur in the field in the State-Owned High School I Tanah Jawa, Simalungun Regency there are still teacher placements that are not in accordance background of the teacher, the ability to manage and use media and learning resourse is not optimal, the teacher's responsibility for the subjects has not met expectation, the school atmosphere has not shown a conductive climate in the teaching and learning process, the ability of teachers to use technology based learning media is not good.

Research related to this research is research Organizational Climate and Job Satisfaction among Academic Staff: Experience from Selected Private Universities in Southeast Nigeria (Okoli, 2018). The focus of this research is to determine the influence of leadership, organizational climate and job satisfaction on teacher performance of teachers in the State-Owned High School I Tanah Jawa, Simalungun Regency.

Application of information technology deemed necessary to be implemented so as to use technology will provide a lot ease and profit in business development (Suhendro, 2017). In educational institutions or schools, the teacher is a true leader, guide and wise director, giving birth to leaders and prospective leaders. The task of the teacher as a professional educator educate, teach, guide, train and improve starting from basic education. Student learning goals reflect the desire to increase exposure to this style teaching and understanding conference error (Leraas et al., 2019). For this reason, there are several things that need to be considered by teachers as educators related to performance, including leadership, organizational climate and job satisfaction. The leader as a personality has a motivation that may not be the same as the motivation of his group members, both in realizing the desire to join and unite in a group and in carrying out activities that become their respective duties and responsibilities.

In the school environment, every leader is a central person who has a great influence on the teacher that is seen in the attitudes and behavior when carrying out their duties and responsibilities. In order to improve the image, work and performance of teachers towards professionalism, it is necessary to unite the directions and views of all ranks of teachers that can be used as guidelines or references in carrying out tasks both managerial and operational in all fields of tasks and school units in an integrated manner.

The change that is always faced by every one who is outside and inside can be an obstacle for the achievement of effective and efficient goals. Based on the background of the introduction above, the problem formulations in this study are: 1) How does leadership influence the performance of teachers in StateOwned High School 1, located in Tanah Jawa, Simalungun Regency? 2) How does the influence of the organizational climate the performance of teachers in State-Owned High School 1, located in Tanah Jawa, Simalungun Regency? 3) How does the influence of job satisfaction the performance of teachers in State-Owned High School 1, located in Tanah Jawa, Simalungun Regency? 4) How does the influence of leadership, organizational climate and job satisfaction in State-Owned High School 1, located in Tanah Jawa, Simalungun 


\section{Regency?}

\section{LITERATURE REVIEW}

People who are working in public and private organizations are discussing the issue of future leadership, whose focus would not be the merits of public or private sector but the scarcity of moral leadership today. Leaders create a culture where their subordinates strive for goal attainment for the success of their organizations. Leadership is an important variable for the quality of education; excellent colleges have leaders who positively influence their stakeholders resulting in high level of students' achievement.

Leadership in the educational institutions such as school is a key factor for the improvement and effectiveness of school climate and job satisfaction of its staff. Educational leaders perform multi-dimensional roles in schools and enhance job satisfaction of their colleague (Munir \& Iqbal, 2018).

Leadership, as one of most widely discussed and researched issues, has been characterized by a variety of definitions, frameworks, and meaning. Such definitions and notions provide a foundation for developing effective leadership in various organizational environments (Almaki, Silong, Idris, \& Abd. Wahat, 2016). Distributed leadership has been operationalized focusing on the perception of favorable conditions that lure leadership distribution, staff empowerment, and shared decision making, etc (Liu \& Werblow, 2019). Leadership is another important organizational condition since leaders have great impact on the direction of, and decision making within, their organizations (Porter, Michael E., 2010). When a communication leader demonstrates great leadership in practice, it helps in the organization increase work engagement and trust in organization. In other words, excellent leader performance in public relations has a direct Influence on professionals' engagement and trust (Meng \& Berger, 2019). From the description above, it can be concluded that a leader in order to get what he wants must have the ability to exert constructive influence on others to achieve predetermined goals. And from some of the above understanding, it can be seen that in leadership there are elements elements: a) Leadership influences others, b)
The ability to move the behavior of subordinates, c) To achieve school or group goals.

Currently, high schools are increasing in number. The large number of schools makes schools'stakeholders need to have a strategy in doing renewal in education. Schools need to have an update in order to stay up and grow, thus, innovation is always required. Innovation can be grown through teachers working in school education organizations. That organizational climate is important in creating conditions to ensure high performance teachers and encouraging them to demonstrate innovative behavior both in class and in school (Izzati, 2017).

Assumption organizational climate that organizational climate interacts with such individual differences variables as needs or values in influencing behavior (Pritchard \& Karasick, 1973). Given the apparent significance of organizational climate with respect to job satisfaction and performance, it would seem to be important to identify the determinants of organizational climate. Organizational climate facilitating such learning behaviours is crucial for enhancing the quality of all the aspects of the innovation process - encompassing the invention, development and implementation of new ideas (Andersson, Moen, \& Brett, 2020). Organizational climate into fairness, innovativeness, and affiliation. Fairness refers to an employee's perception that organizational practices are just and fair. This builds trust among employees and can motivate employees to share knowledge. Innovativeness concerns employees' perceptions that the organization highly regards creativity and innovation (Al-Kurdi, ElHaddadeh, \& Eldabi, 2020).

Job satisfaction is a kind of positive or cheerful emotional state that employees show in their work resulting from an evaluation of their jobs (Chu, Fu, \& Liu, 2019). Increase in job satisfaction is obtained when the individual's wage change exceeds the average wage change for his reference group (Diriwaechter \& Shvartsman, 2018). Job satisfaction and quality of life as indicators of well-being among teachers. In particular, the well being of teachers has been recently emphasized since it affects not only teacher 
retention but also negative outcomes. In the review of the literature on teachers well-being, emotional and physical health were suggested topics for future research. Job satisfaction was assessed via the internal job satisfaction subscale from the teacher job satisfaction questionnaire developed (Yuh \& Choi, 2017). The researcher made observations at State-Owned High School 1, located in Tanah Jawa, Simalungun Regency, that the role of Human Resources in this case the attention of the leadership was very influential in supporting the achievement of various targets to be achieved. Human Resources is the main resource that determines the success or failure of something. In this effort to utilize and mobilize Human Resources, an effective activity is needed so that in the end the teacher is creative with his ideas. The second variable that affects the performance of teachers of State-Owned High School 1, located in Tanah Jawa, Simalungun Regency is the influence of the organization. A good organizational climate can include the availability of public facilities, a clean, spacious and neat workspace, adequate air circulation and lighting, and the creation of a harmonious work atmosphere that can be seen from active interactions between teachers. One of the things that can improve teacher performance is a good organizational environment or a good organizational climate. Interaction between teacher and student can lead to a positive school atmosphere and can also lead to a negative school atmosphere. A positive school atmosphere will occur when interactions in schools occur between students and teachers, where in these interactions communication occurs in the form of cooperation, please help, tolerance between smart and less clever children, between the rich and the underprivileged, norms the association of life and the discipline of the school and the school are adhered to with flexible discipline, and open communication occurs. Organizational climate conducted by researchers at the StateOwned High School 1, located in Tanah Jawa, Simalungun Regency, has not really been realized and work skills still need to be improved, causing teacher performance is not optimal in carrying out their work.

The third variable that influences the performance of teachers in State-Owned High
School 1, located in Tanah Jawa, Simalungun Regency is job satisfaction. Low job satisfaction in organizations is a series of decreased task performance, increased absenteeism, and decreased organizational morale. Whereas at the individual level, work dissatisfaction is related to a great desire to leave the workplace, increased work stress, and the emergence of various psychological and physical problems.

Based on this theory, the State-Owned High School 1, located in Tanah Jawa, Simalungun Regency must try to improve the quantity and quality of teachers. The role of the teacher as the main actor in working is very large, especially to support other sectors. With quality resources, high quality can be owned by the State High School I Tanah Jawa Simalungun Regency, so as to produce a quality output in accordance with the demands that continue to grow at this time.

\section{RESEARCH METHODS}

The location of this research is in the StateOwned High School 1, located in Tanah Jawa, Simalungun Regency. The object of this research is the teacher of the State-Owned High School 1, located in Tanah Jawa, Simalungun Regency, where this research is a causal study, that is the research which aims to analyze the influence of three independent variables on one dependent variable. The independent variables referred to in this study are leadership as a variable (X1), organizational climate as a variable (X2), job satisfaction as a variable (X3) and teacher performance as a variable $(\mathrm{Y})$ which is a dependent variable. The research framework is :

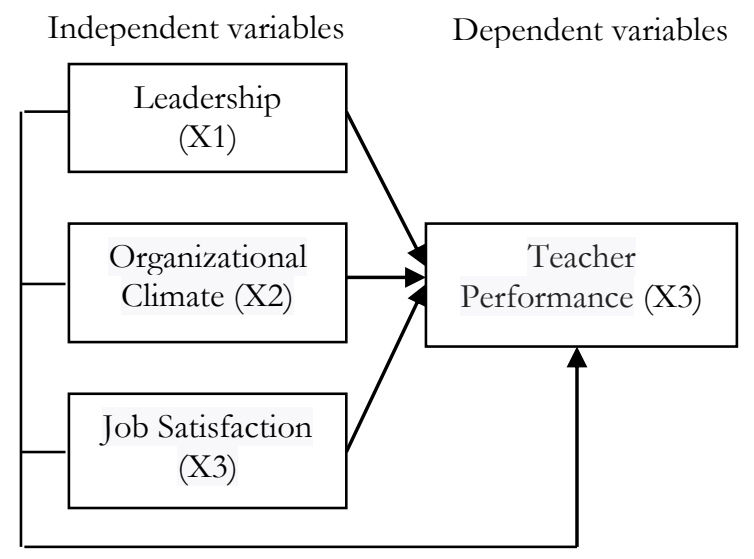

Figure 1. Framework

The hypotheses in this research are: 
1. Leadership influence the performance of teachers in the State-Owned High School 1, located in Tanah Jawa, Simalungun Regency.

2. Organizational climate influence the performance of teachers in the StateOwned High School 1, located in Tanah Jawa, Simalungun Regency.

3. Job satisfaction influence the performance of teachers in the State-Owned High School 1, located in Tanah Jawa, Simalungun Regency.

4. Leadership, organizational climate and job satisfaction influence in the State-Owned High School 1, located in Tanah Jawa, Simalungun Regency.

Data analysis techniques in this research uses the form of distribution to respondents to the overall concept being measured. From the distribution of the respondents' answers, then a trend will be obtained from all available answers. To get the tendency of respondents' answers to each variable. Correct and accurate grouping of answer data, then calculated and summed until it is tangible in a useful form. Based on the results of the table, the results were agreed to make table data in order to get a relationship or influence between the existing variables.

Quantitative analysis is a form of analysis that uses numbers and calculations using statistical methods, then the data must be clarified in certain categories using certain tables, to make it easier to analyze using the SPSS program, which aims to determine the effect of independent variables on the dependent variable by using multiple linear regression analysis.

The population of research subjects where the individual who will be subject to behavior or can be said to be the total object of research to be studied. There are 55 teachers in the State-Owned High School 1, located in Tanah Jawa, Simalungun Regency.
Table 1. Population Framework of Public State-Owned High School 1, Tanah Jawa Simalungun Regency

\begin{tabular}{|ccc|}
\hline No & Information & Amount \\
\hline 1 & Civil Servant Teacher & 53 \\
2 & Honor Teacher & 2 \\
& & 55 \\
\hline
\end{tabular}

Taking samples for less than 100 subjects, it is better to take all of them so that the research is a population study. Furthermore, if the number of subjects is large, it can be taken between $10-15 \%$, or $20-25 \%$ or more. With total sampling technique, the sample in this study amounted to 55 people or the entire population. Base on teacher data, the population of this study were 55 teachers at State-Owned High School 1 Tanah Jawa, Simalungun Regency. To analyze using the SPSS program, which aims to determine the Influence of independent variables on the dependent variable using multiple linear regression analysis.

\section{Hypothesis test}

To test the research hypothesis using multiple linear regression analysis that is looking at the influence of the independent variable (independent variable) on the dependent variable (the dependent variable), by using a mathematical equation that is multiple linear regression analysis with the formula:

$$
\begin{aligned}
\mathrm{Y}=\alpha+\beta_{1} \mathrm{X}_{1} & +\beta_{2} \mathrm{X}_{2}+\beta_{3} \mathrm{X}_{3}+\varepsilon \\
\mathrm{Y} & =\text { Teacher Performance } \\
\alpha & =\text { Constant } \\
\mathrm{X} 1 & =\text { Leadership } \\
\mathrm{X} 2 & =\text { Organizational Climate } \\
\mathrm{X} 3 & =\text { Job satisfaction } \\
\beta_{1}, \beta_{2}, \beta_{3} & =\text { Regression Coefficient } \\
\varepsilon & =\text { Standard Error }
\end{aligned}
$$

Multiple linear regression analysis includes the Coefficient of Determination (R2) test aimed at finding out the effective contribution $\mathrm{X} 1$; X2; $\mathrm{X} 3$ variable to explain the variable $\mathrm{Y}$, $\mathrm{F}$ test aims to see the Influence simultaneously of variable $\mathrm{X} 1 ; \mathrm{X} 2 ; \mathrm{X} 3$ on the $\mathrm{Y}$ variable and $\mathrm{t}$ test to see the partial Influence of each variable 
$\mathrm{X} 1$; X2; $\mathrm{X} 3$ with respect to the variable $\mathrm{Y}$, and for more details, see the following explanation:

\section{F Test (Simultaneous Testing)}

This test is conducted to determine whether all independent variables together (simultaneously) can affect the dependent variable. The method used is to compare the calculated $\mathrm{F}_{\text {value }}$ with $\mathrm{F}_{\text {table }}$ with the following conditions:

$\mathrm{H} 0: \beta=0$, means that there is no significant influence of the independent variables on the dependent variable simultaneously.

$\mathrm{Ha}: \beta>0$, means that there is a significant influence of the independent variables on the dependent variable simultaneously

The confidence level used is $95 \%$ or a significant level of $5 \%(\alpha=0.05)$ with the following criteria:

a. If $\mathrm{F}_{\text {count }}>\mathrm{F}_{\text {table }}$ and probability (significant value $)<$ significance level of $5 \% \quad(\alpha=$ $0.05)$ then $\mathrm{Ha}$ is accepted and $\mathrm{HO}$ is rejected, meaning that there are independent variables together have a significant Influence on the dependent variable.

b. If $\mathrm{F}_{\text {count }}<\mathrm{F}_{\text {table }}$ and probability (significance value $)>$ significance level of $5 \% \quad(\alpha=$ $0.05)$ then $\mathrm{HO}$ is accepted and $\mathrm{Ha}$ is rejected, meaning that no independent variable together has no significant Influence on the dependent variable.

\section{T Test (Partial Testing)}

$\mathrm{T}$ test was conducted to determine the Influence of each independent variable partially on the dependent variable. $T$ test is done by comparing $t_{\text {count }}$ to $t_{\text {table }}$ with the following conditions:

$\mathrm{H} 0: \beta=0$, meaning that there is no significant Influence of each independent variable on the dependent variable.

$\mathrm{Ha}: \beta>0$, means that there is a significant Influence of each independent variable on the dependent variable partially.

The confidence level used is $95 \%$ or a significant level of $5 \%(\alpha=0.05)$ with the following criteria:

a. If $t_{\text {count }}>t_{\text {table }}$ and probability (significant value $)<$ significance level of $5 \% \quad(\alpha=$ $0.05)$ then $\mathrm{Ha}$ is accepted and $\mathrm{HO}$ is rejected, meaning there is a significant
Influence of each independent variable on the dependent variable.

b. If $\mathrm{t}_{\text {count }}<\mathrm{t}_{\text {table }}$ and probability (significance value $)>$ significance level of $5 \% \quad(\alpha$ $=0.05)$ then $\mathrm{HO}$ is accepted and $\mathrm{Ha}$ is rejected, meaning there is no significant Influence of each independent variable on the dependent variable. Where $t_{\text {table }}$ is determined by finding the free degrees $\mathrm{df}=$ $\mathrm{N}-\mathrm{k}$.

\section{Coefficient of Determination (R2)}

The coefficient of determination (R2) basically measures how much the ability of the independent variable (X1), (X2) and (X3) in explaining the variation of the dependent variable $(\mathrm{Y})$. The coefficient of determination is between zero (0) to one (1). R2 value below zero means the ability of independent variables in explaining the variation of the dependent variable is very limited. A value close to one means that the independent variables provide almost all the information needed to predict the dependent variation. The fundamental drawback of using the coefficient of determination is the bias towards the number of independent variables entered into the model. Every additional one independent variable, then R2 must increase. Therefore, many researchers recommend using the value of Adjusted R2 (Adjusted R Square) when evaluating where the best regression model. Different from R2, the adjusted R2 value can go up or down if an independent variable is added to the model. For more than two independent variables you should use the Adjusted R2 value.

\section{RESULTS AND DISCUSSION \\ Results \\ Data Quality Test}

1. Validity Test

Descriptive Analysis of Leadership Variables (X1)

The lowest value and the highest value, in this case the lowest value $=$ number of respondents (number of respondents 55, then the lowest value is 55). While the highest value, the lowest value multiplied by the weight of the highest value is $55 \times 5=275$. Thus the lowest value is 40 and the highest value is 275 . Alternative answers there are five choices 
(according to the Likert scale), then the assessment category must also be five, for that the next step is to determine the interval of the interval from the lowest value to the highest value to obtain five assessment categories. Interval distance can be done with the following calculation:

Interval Distance $=(275-55) / 5=44$. The assessment categories for each item of statement and the assessment of the variables studied are in the table below, which is the category score table.

Table 2. Table Scores Category

\begin{tabular}{cll}
\hline No & \multicolumn{1}{c}{ Category } & \multicolumn{1}{c}{ Score } \\
\hline 1 & Very Poor & $44-88$ \\
2 & Poor & $89-133$ \\
3 & Sufficient & $134-178$ \\
4 & Good & $179-223$ \\
5 & Excellent & $224-268$ \\
\hline
\end{tabular}

In this research the ranking sequence using the Likert scale as follows:

1. Strongly Agree $=$ Score 5

2. Agreeable $=$ Score 4

3. Less Agreeable $=$ Score 3

4. Disagree $=$ Score 2

5. Strongly Disagree $=$ Score 1

a. Leadership Variable Validity Test Results (X1)

The validity test is a measure that shows the levels of validity or validity of an instrument. To test the validity of the instrument, it was done by correcting the answer score obtained from each item with the total score of all instrument items. The validity test is used to measure the validity of a questionnaire. A questionnaire is said to be valid if the questions on the questionnaire are able to reveal what should be measured. The assumption used in the validity test is that if r-count (seen in the corrected item-total correlation) is greater than $r$ table ( $r$ count $>r$ table) then the item is declared valid. The value of $r$ table used for validity testing is 0.361 .

The approach used in the validity test in this study is to compare the calculated $r$ value with the $r$ table so that it can be seen which question items are valid and invalid. Item questions are declared valid if $r$-count $>$ r-table, in this study as many respondents were 55 teachers, then the value of $r$ table can be obtained through df (degree of freedom), which is the number of respondents minus two. So the df value is 55 , then $\mathrm{r}$-table $=0.361$. The value can be seen in each table to test the validity of the research variable data.

Table 3. Output validity test of the Leadership variable

\begin{tabular}{cccc}
\hline $\begin{array}{c}\text { Statement } \\
\text { Items }\end{array}$ & $\mathrm{r}_{\text {count }}$ & $\mathrm{r}_{\text {table }}$ & Information \\
\hline Q1 &, 505 &, 361 & Valid \\
Q2 &, 480 &, 361 & Valid \\
Q3 &, 615 &, 361 & Valid \\
Q4 &, 479 &, 361 & Valid \\
Q5 &, 543 &, 361 & Valid \\
Q6 &, 415 &, 361 & Valid \\
Q7 &, 661 &, 361 & Valid \\
Q8 &, 600 &, 361 & Valid \\
Q9 &, 415 &, 361 & Valid \\
Q10 &, 526 &, 361 & Valid \\
\hline
\end{tabular}

The results of the validity test shown in table 3 show that all elements of the 10 question item questionnaire from the quality of the system are declared valid, this is proven because $r$ count is greater than r-table (0.361). All questionnaires can be used as a data collection tool.

b. Organizational Climate Variable Validity Test Results (X2)

Table 4. Output validity test of the Organizational Climate variable

\begin{tabular}{cccc}
\hline $\begin{array}{c}\text { Statement } \\
\text { Items }\end{array}$ & $\mathrm{r}_{\text {count }}$ & $\mathrm{r}_{\text {table }}$ & Information \\
\hline Q1 &, 672 &, 361 & Valid \\
Q2 &, 619 &, 361 & Valid \\
Q3 &, 479 &, 361 & Valid \\
Q4 &, 556 &, 361 & Valid \\
Q5 &, 735 &, 361 & Valid \\
Q6 &, 700 &, 361 & Valid \\
Q7 &, 709 &, 361 & Valid \\
Q8 &, 516 &, 361 & Valid \\
Q9 &, 406 &, 361 & Valid \\
Q10 &, 770 &, 361 & Valid \\
\hline
\end{tabular}


The results of the validity test shown in table 4 show that all elements of the 10 question item questionnaire from the quality of the system are declared valid, this is proven because $r$ count is greater than r-table (0.361). All questionnaires can be used as a data collection tool.

c. Job Satisfaction Variable Validity Test Results (X3)

Table 5. Output validity test of the Job Satisfaction variable

\begin{tabular}{cccc}
\hline $\begin{array}{c}\text { Statement } \\
\text { Items }\end{array}$ & $\mathrm{r}_{\text {count }}$ & $\mathrm{r}_{\text {table }}$ & Information \\
\hline Q1 &, 684 &, 361 & Valid \\
Q2 &, 545 &, 361 & Valid \\
Q3 &, 684 &, 361 & Valid \\
Q4 &, 608 &, 361 & Valid \\
Q5 &, 673 &, 361 & Valid \\
Q6 &, 640 &, 361 & Valid \\
Q7 &, 481 &, 361 & Valid \\
Q8 &, 580 &, 361 & Valid \\
Q9 &, 640 &, 361 & Valid \\
Q10 &, 481 &, 361 & Valid \\
\hline
\end{tabular}

The results of the validity test shown in table 3 show that all elements of the 10 question item questionnaire from the quality of the system are declared valid, this is proven because $r$ count is greater than r-table (0.361). All questionnaires can be used as a data collection tool.

d. Teacher Performance Variable Validity Test Results (Y)

Table 6. Output validity test of the Teacher Performance variable

\begin{tabular}{cccc}
\hline $\begin{array}{c}\text { Statement } \\
\text { Items }\end{array}$ & $\mathrm{r}_{\text {count }}$ & $\mathrm{r}_{\text {table }}$ & Information \\
\hline Q1 &, 653 &, 361 & Valid \\
Q2 &, 535 &, 361 & Valid \\
Q3 &, 588 &, 361 & Valid \\
Q4 &, 653 &, 361 & Valid \\
Q5 &, 599 &, 361 & Valid \\
Q6 &, 653 &, 361 & Valid \\
Q7 &, 524 &, 361 & Valid \\
Q8 &, 653 &, 361 & Valid \\
Q9 &, 535 &, 361 & Valid \\
Q10 &, 465 &, 361 & Valid \\
\hline
\end{tabular}

The results of the validity test shown in table 3 show that all elements of the 10 question item questionnaire from the quality of the system are declared valid, this is proven because $r$ count is greater than r-table (0.361). All questionnaires can be used as a data collection tool.

\section{Reliability Test}

Leadership Variable Reliability Test Results (X1)

Output Reliability Test Leadership variable

Table 6. Reliability Statistics

\begin{tabular}{cc}
\hline Cronbach's Alpha & N of Items \\
\hline, 725 & 11 \\
\hline
\end{tabular}


Table 7. Item-Total Statistics

\begin{tabular}{lcccc}
\hline & $\begin{array}{l}\text { Scale Mean if } \\
\text { Item Deleted }\end{array}$ & \multicolumn{2}{c}{ Scale Variance Corrected Item-TotalCronbach's Alpha if } \\
if Item Deleted Correlation & Item Deleted \\
\hline P1 & 77,1636 & 92,510 &, 433 &, 708 \\
P2 & 77,5455 & 92,845 &, 406 &, 710 \\
P3 & 77,9636 & 87,184 &, 531 &, 692 \\
P4 & 77,5636 & 91,399 &, 387 &, 708 \\
P5 & 77,5818 & 90,655 &, 465 &, 703 \\
P6 & 77,5818 & 94,581 &, 344 &, 715 \\
P7 & 77,5636 & 88,325 &, 598 &, 692 \\
P8 & 77,4545 & 91,771 &, 545 &, 703 \\
P9 & 77,5818 & 94,581 &, 344 &, 715 \\
P10 & 77,2000 & 92,533 &, 460 &, 707 \\
Leadership & 40,8000 & 25,200 & 1,000 &, 706 \\
\hline
\end{tabular}

From the results of the above table, it can be seen that the $r$ count value in the Cronbach's alpha column if item deleted is all greater than the $r_{\text {table }}$ value, then all question items for the Leadership variable are declared reliable, in the reliability statistics table it is known that the Alpha Cronbach value is 0.725 . Because the Alpha Cronbach value $>r_{\text {table }}$, the Organizational Climate Variable Reliability Test Results (X2)

Output Reliability Test Organizational Climate Variable questionnaire used is reliable.

Table 9. Item-Total Statistics

\begin{tabular}{lcccc}
\hline & $\begin{array}{c}\text { Scale Mean if } \\
\text { Item Deleted }\end{array}$ & $\begin{array}{c}\text { Scale Variance if } \\
\text { Item Deleted }\end{array}$ & $\begin{array}{c}\text { Corrected Item- } \\
\text { Total Correlation }\end{array}$ & $\begin{array}{c}\text { Cronbach's Alpha if } \\
\text { Item Deleted }\end{array}$ \\
\hline P1 & 75,6909 & 134,292 &, 622 &, 727 \\
P2 & 75,8182 & 136,485 &, 568 &, 732 \\
P3 & 76,2909 & 137,692 &, 402 &, 739 \\
P4 & 75,9818 & 136,166 &, 489 &, 734 \\
P5 & 75,7818 & 133,877 &, 696 &, 725 \\
P6 & 75,6364 & 135,125 &, 659 &, 728 \\
P7 & 75,6364 & 135,569 &, 671 &, 728 \\
P8 & 75,9273 & 138,624 &, 454 &, 738 \\
P9 & 76,1273 & 141,854 &, 343 &, 746 \\
P10 & 76,0727 & 128,846 &, 726 &, 714 \\
Organizational & 39,9455 & 37,460 & 1,000 &, 815 \\
Climate & & & &
\end{tabular}

From the results of the above table it can be seen that the $r_{\text {count }}$ value in the Cronbach's alpha column if item deleted is all greater than the $r_{\text {table }}$ value, then all question items for the Organizational Climate variable are declared reliable, in the reliability statistics table it is known that the Alpha Cronbach value is 0.752 . Because the Alpha Cronbach value $>r_{\text {table }}$, the questionnaire used is reliable.

Job Satisfaction Variable Reliability Test Results (X3)
Table 8. Reliability Statistics

\begin{tabular}{cc}
\hline Cronbach's Alpha & N of Items \\
\hline, 752 & 11 \\
\hline
\end{tabular}

Output Reliability Test Job Satisfaction Variable

Table 10. Reliability Statistics

\begin{tabular}{cc}
\hline Cronbach's Alpha & N of Items \\
\hline, 749 & 11 \\
\hline
\end{tabular}


Table 11. Item-Total Statistics

\begin{tabular}{|c|c|c|c|c|c|}
\hline & $\begin{array}{c}\text { Scale Mean if Item } \\
\text { Deleted }\end{array}$ & $\begin{array}{l}\text { Scale Varia } \\
\text { Item Del }\end{array}$ & $\begin{array}{l}\text { nce if } \\
\text { eted }\end{array}$ & $\begin{array}{l}\text { Corrected Item- } \\
\text { Total Correlation }\end{array}$ & $\begin{array}{l}\text { Cronbach's Alpha if } \\
\text { Item Deleted }\end{array}$ \\
\hline$\overline{\mathrm{P} 1}$ & 74,8182 & 74,855 & &, 630 &, 720 \\
\hline P2 & 74,8182 & 78,707 & & ,493 & ,735 \\
\hline P3 & 74,8182 & 74,855 & & 630 &, 720 \\
\hline P4 & 74,8000 & 77,274 & &, 555 & ,730 \\
\hline P5 & 74,7455 & 76,267 & & ,626 & ,725 \\
\hline P6 & 74,8182 & 76,220 & &, 586 & ,726 \\
\hline P7 & 74,8545 & 78,719 & & ,414 & ,737 \\
\hline P8 & 74,9091 & 77,300 & &, 522 & ,731 \\
\hline P9 & 74,8182 & 76,220 & &, 586 & ,726 \\
\hline P10 & 74,8545 & $78,71 \mathrm{c}$ & & ,414 &, 737 \\
\hline Job Satisfaction & 39,3818 & 21,203 & & 1,000 &, 805 \\
\hline \multirow{3}{*}{\multicolumn{3}{|c|}{$\begin{array}{l}\text { From the results of the above table, it can } \\
\text { be seen that the } r \text { count value in the } \\
\text { Cronbach's alpha column if item deleted is all } \\
\text { greater than the rtable value, then all the } \\
\text { questions for the variable Job satisfaction } \\
\text { stated reliable, in the reliability statistics table } \\
\text { known Alpha Cronbach value of } 0.749 \text {. } \\
\text { Because the Alpha Cronbach value }>r_{\text {table }} \text {, the }\end{array}$}} & \multicolumn{3}{|c|}{$\begin{array}{l}\text { Teacher Performance Variable Reliability Test } \\
\text { Results (Y) } \\
\text { Output Realibility Test Teacher Performance } \\
\text { Variable }\end{array}$} \\
\hline & & & & ronbach's Alpha & $\mathrm{N}$ of Items \\
\hline & & & &, 743 & 11 \\
\hline
\end{tabular}
questionnaire used is reliable.

Table 13. Item-Total Statistics

\begin{tabular}{lcccc}
\hline & $\begin{array}{c}\text { Scale Mean if } \\
\text { Item Deleted }\end{array}$ & $\begin{array}{c}\text { Scale Variance if } \\
\text { Item Deleted }\end{array}$ & $\begin{array}{c}\text { Corrected Item-Total } \\
\text { Correlation }\end{array}$ & $\begin{array}{c}\text { Cronbach's Alpha if } \\
\text { Item Deleted }\end{array}$ \\
\hline P1 & 79,2545 & 90,601 &, 586 &, 713 \\
P2 & 79,1455 & 96,127 &, 479 &, 729 \\
P3 & 79,0182 & 94,426 &, 530 &, 723 \\
P4 & 78,7818 & 93,952 &, 605 &, 720 \\
P5 & 78,7091 & 95,840 &, 553 &, 726 \\
P6 & 78,7818 & 93,952 &, 605 &, 720 \\
P7 & 79,2182 & 93,433 &, 440 &, 725 \\
P8 & 79,2545 & 90,601 &, 586 &, 713 \\
P9 & 79,1455 & 96,127 &, 479 &, 729 \\
P10 & 79,0909 & 96,788 &, 399 &, 732 \\
Teacher & 41,6000 & 25,948 & 1,000 &, 781 \\
Performance & & &
\end{tabular}

From the results of the above table, it can be seen that the $r_{\text {count }}$ value in the Cronbach's alpha column if item deleted is all greater than the $r_{\text {table }}$ value, then all items for the Teacher Performance variable are declared reliable, in the reliability statistics table it is known that the Alpha Cronbach value is 0.743 . Because the Alpha Cronbach value $>r_{\text {table }}$, the questionnaire used is reliable.

\section{Classic Assumption Test \\ a. Normality Test}

Normality test is not carried out on each variable but on the residual value. Test the normality of research data is to test whether in the statistical model the research variables are normally or not normally distributed. To test whether the data distribution is normal or not, one of them using the normal drawing method Probability Plots is used to deduce whether the

Dedi Suhendro, Ilham Syahputra Saragih 
analysis model meets the normal assumptions, by spreading the data around the diagonal line and following the direction of the diagonal line, the data meets the normal assumptions in the analysis model, which can be seen in the image below:

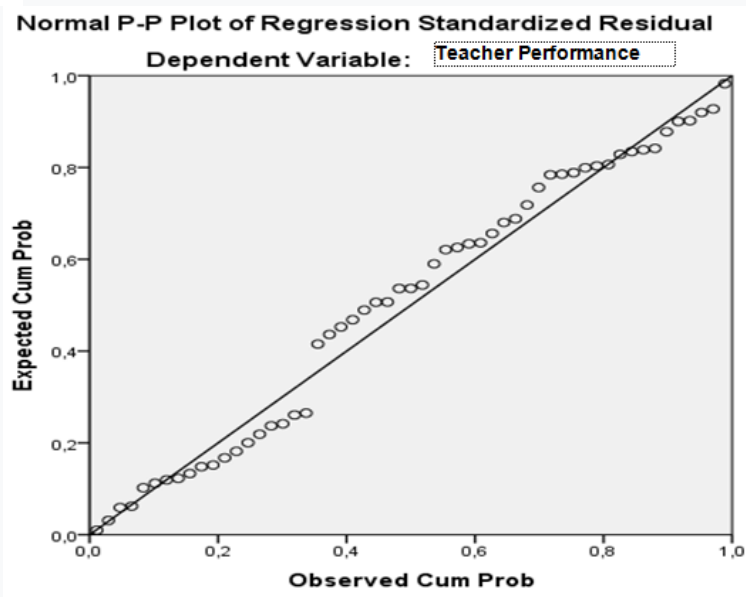

Figure 2. P-Plot Normality Test

\section{b. Multicollinearity Test}

If there is multicollinearity, the regression coefficient becomes uncertain, the error rate becomes very large and is usually marked by a very large coefficient of determination but in the partial test of the regression coefficient, there is no or even if there is very little significant regression coefficient. In this reasearch the value of Variance Inflantion Factor (VIF) is used as an indicator of the presence or absence of multicollinearity among the independent variables.

Table 14. Multicollinearity Test Results

\begin{tabular}{lcc}
\hline \multirow{2}{*}{ Variabel } & \multicolumn{2}{c}{ Collinearity Statistics } \\
\cline { 2 - 3 } & Tolerance & VIF \\
\hline Leadership & .426 & 2.145 \\
Organizational Climate & .428 & 2.337 \\
Job satisfaction & .883 & 1.133 \\
\hline
\end{tabular}

a. Dependent Variable: Teacher performance

Based on the obtained VIF values as shown in the table above, $2,145,2,337,1,133$, there is a high enough correlation between independent variables, where the VIF value of the two independent variables is less than 10 and it can be concluded that there is no multicollinearity between the two independent variables.

\section{c. Heteroscedasticity Test}

This heteroscedasticity test is used in the regression model to see the difference in variance from one residual to another observation.The best model is not heteroscedasticity. Analysis of the Scatterplot image states that there is no heteroscedasticity of multiple linear regression models if:

a. Data points spread above and below or around the number 0

b. Data points do not collect only above or below

c. Spread of points should not form a wavy pattern then widened and narrowed again.

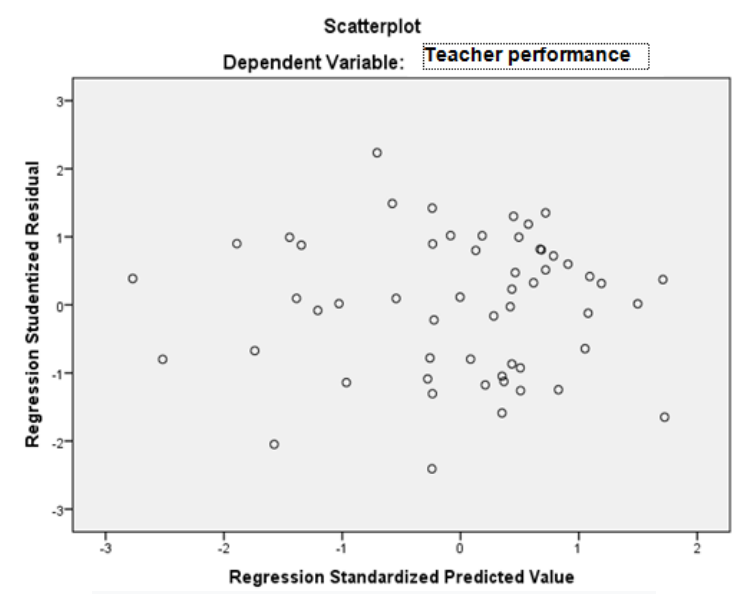

Figure 3. Heteroscedasticity Graph

Regression model is considered not to occur heteroscedasticity if the points spread randomly and do not form a certain pattern that is clear and spread above or below zero on the $\mathrm{Y}$ axis. Figure 3 shows that the points spread randomly so there is no heteroscedasticity. The results of the Glejser test processing can be seen in the following table 15: 
Table 15. Heteroscedasticity Glejser Test Results

Coefficients $^{2}$

\begin{tabular}{lcccccc}
\hline \multirow{2}{*}{ Model } & \multicolumn{2}{c}{$\begin{array}{c}\text { Unstandardized } \\
\text { Coefficients }\end{array}$} & $\begin{array}{c}\text { Standardized } \\
\text { Coefficients }\end{array}$ & \multirow{2}{*}{ t } & Sig. \\
\cline { 2 - 4 } & $\mathrm{B}$ & Std. Error & Beta & & \\
\hline (Constant) & 2,813 & 3,762 &, 161 & &, 748 &, 458 \\
Leadership &, 064 &, 081 &,- 217 &, 795 &, 430 \\
Organizational Climate &,- 071 &, 069 &, 024 & $-1,026$ &, 310 \\
Job satisfaction &, 010 &, 064 & &, 160 &, 873 \\
\hline
\end{tabular}

a. Dependent Variable: ABS_RES

Table 15 Leadership variables (X1) of 0.430, Organizational Climate (X2) of 0.310 and Job Satisfaction (X3) of 0.873 none of the statistically significant independent variables affect the absolute residual dependent variable (abs_res).

\section{Discussion}

This researcher will test the truth of the hypothesis either simultaneously or together, or partially or individually and to facilitate researchers in data processing, the SPSS Program version 20.0 is used.
1. Influence of Leadership on Teacher Performance in the State-Owned High School 1, located in Tanah Jawa, Simalungun Regency.

To find out the influence of the Principal's Leadership on Teacher Performance in the State-Owned High School 1, located in Tanah Jawa, Simalungun Regency used t-test, while to see the magnitude of the Influence used Beta or Standardized Coefficient numbers.

Table 16. Coeficients ${ }^{\mathrm{a}}$ influence Principal Leadership on Teacher Performance

\begin{tabular}{|c|c|c|c|c|c|}
\hline \multirow[t]{2}{*}{ Model } & \multicolumn{2}{|c|}{$\begin{array}{l}\text { Unstandardized } \\
\text { Coefficients }\end{array}$} & \multirow{2}{*}{$\begin{array}{c}\begin{array}{c}\text { Standardized } \\
\text { Coefficients }\end{array} \\
\text { Beta }\end{array}$} & \multirow[t]{2}{*}{$\mathrm{T}$} & \multirow[t]{2}{*}{ Sig. } \\
\hline & B & Std. Error & & & \\
\hline (Constant) & $-2,026$ & 6,899 & &,- 294 &, 770 \\
\hline Leadership & ,049 & ,149 & ,048 & 3,327 &, 745 \\
\hline
\end{tabular}

a. Dependent Variable: Teacher Performance

From the above table, $t_{\text {count }}$ value is 3,327 . Obtained $t_{\text {table }}$ value of 1.675. With the hypothesis criteria If $\mathrm{t}_{\text {count }}>\mathrm{t}_{\text {table }}$, then $\mathrm{H} 0$ is rejected and $\mathrm{Ha}$ is accepted and if $\mathrm{t}_{\text {count }}<\mathrm{t}_{\text {table, }}$, then $\mathrm{HO}$ is accepted and $\mathrm{Ha}$ is rejected. From the calculation results obtained $t_{\text {count }}>t_{\text {table }}$ $(3,327>1,675)$ and significance value $0,000<$ 0.05 , so $\mathrm{H} 0$ is rejected and $\mathrm{Ha}$ is accepted. This means that the Leadership variable has a positive and significant influence on Teacher Performance in the State-Owned High School 1, located in Tanah Jawa, Simalungun Regency. The magnitude of the influence of leadership on teacher performance by 0.3327 or $33.27 \%$.
2. Organizational climate influence the performance of teachers in the StateOwned High School 1, located in Tanah Jawa, Simalungun Regency.

To find out the influence of Organizational Climate on Teacher Performance in the StateOwned High School 1, located in Tanah Jawa, Simalungun Regency used t-test, while to see the magnitude of influence used Beta or Standardized Coefficient numbers. 
Table 17. Coeficients ${ }^{\mathrm{a}}$ influence of Organizational Climate on Teacher Performance

\begin{tabular}{lccccc}
\hline \multirow{2}{*}{ Model } & \multicolumn{2}{c}{$\begin{array}{c}\text { Unstandardized } \\
\text { Coefficients }\end{array}$} & $\begin{array}{c}\text { Standardized } \\
\text { Coefficients }\end{array}$ & \multirow{2}{*}{ T Sig. } \\
\cline { 2 - 4 } & $\mathrm{B}$ & Std. Error & Beta & & \\
\hline (Constant) & $-2,026$ & 6,899 & &,- 294 &, 770 \\
Organizational Climate &, 551 &, 127 &, 662 & 4,330 &, 000 \\
\hline
\end{tabular}

a. Dependent Variable: Teacher Performance

From the above table, the $\mathrm{t}_{\text {value }}$ of 4.234 is obtained. Under these conditions, a $t_{\text {table }}$ value of 1,675 was obtained. With the hypothesis criteria If $t_{\text {count }}>t_{\text {table }}$, then $\mathrm{H} 0$ is rejected and $\mathrm{Ha}$ is accepted and if $\mathrm{t}_{\text {count }}<\mathrm{t}_{\text {table, }}$, then $\mathrm{HO}$ is accepted and $\mathrm{Ha}$ is rejected. From the calculation results obtained $t_{\text {count }}>t_{\text {table }}(4,330$ $>1,686)$ and significance value $0,000<0.05$, so $\mathrm{HO}$ is rejected and $\mathrm{Ha}$ is accepted. This means that the Organizational Climate variable has a positive and significant influence on Teacher Performance in the State-Owned High School 1, located in Tanah Jawa, Simalungun Regency. The magnitude of the influence of organizational climate on teacher performance by 4,330 . or $43.30 \%$.

3. Job satisfaction influence the performance of teachers in the StateOwned High School 1, located in Tanah Jawa, Simalungun Regency.

To find out job satisfaction influence the performance of teachers in the State-Owned High School 1, located in Tanah Jawa, Simalungun Regency used the t-test, while to see the amount of influence used Beta or Standardized Coefficient numbers.

Tabel 18. Coeficients ${ }^{\mathrm{a}}$ influence of Job Satisfaction on Teacher Performance

\begin{tabular}{lccccc}
\hline \multirow{2}{*}{ Model } & \multicolumn{2}{c}{$\begin{array}{c}\text { Unstandardized } \\
\text { Coefficients }\end{array}$} & $\begin{array}{c}\text { Standardized } \\
\text { Coefficients }\end{array}$ & \multirow{2}{*}{ T } & Sig. \\
\cline { 2 - 4 } & $\mathrm{B}$ & Std. Error & Beta & & \\
\hline (Constant) & $-2,026$ & 6,899 & &,- 294 &, 770 \\
Kepuasan Kerja &, 499 &, 118 &, 451 & 4,234 &, 000 \\
\hline
\end{tabular}

a. Dependent Variable: Kinerja Guru

From the above table, $t_{\text {count }}$ value is 4,234 . Obtained $t_{\text {table }}$ value of 1.675 . With the hypothesis criteria If $t_{\text {count }}>t_{\text {table, }}$, then $\mathrm{H} 0$ is rejected and $\mathrm{Ha}$ is accepted and if $\mathrm{t}_{\text {count }}<\mathrm{t}_{\text {table }}$, then $\mathrm{HO}$ is accepted and $\mathrm{Ha}$ is rejected. From the calculation results obtained $t_{\text {count }}>t_{\text {table }}$ $(4,234>1,675)$ and significance value $0,000<$ 0.05 , so $\mathrm{H} 0$ is rejected and $\mathrm{Ha}$ is accepted. This means that the Job Satisfaction variable has a positive and significant influence on Teacher Performance in the State-Owned High School 1, located in Tanah Jawa, Simalungun Regency. The magnitude of the influence of job satisfaction on teacher performance by 0.4234 or $42.34 \%$.

\section{Leadership, Organizational Climate and Job Satisfaction influence in the State- Owned High School 1, located in Tanah Jawa, Simalungun Regency.}

Influence of Leadership, Organizational Climate and Job Satisfaction on Teacher Performance in the State-Owned High School 1, located in Tanah Jawa, Simalungun Regency. simultaneously, it can be seen from the calculation results in the summary model, specifically the R-square figures below:

Organizational Climate and Job Satisfaction is $49.90 \%$, while the remaining $51.00 \%$ is caused by other variables not examined or not included in this research model. The $\mathrm{F}_{\text {count }}$ value is 56.808 and $F_{\text {table }}$ value of 2,783. With the hypothesis criteria if $\mathrm{F}_{\text {count }}>\mathrm{F}_{\text {table }}$, then $\mathrm{H} 0$ is rejected and $\mathrm{Ha}$ is accepted and if $\mathrm{F}_{\text {count }}<$ $\mathrm{F}_{\text {table }}$, then $\mathrm{H} 0$ is accepted and $\mathrm{Ha}$ is rejected The table above shows that the magnitude of R-Square (R2) is 0.490. Influence, Leadership, 
Organizational Climate and Job Satisfaction on Teacher Performance in the State-Owned High School 1, located in Tanah Jawa, Simalungun Regency by $49.00 \%$, while the remaining $51.00 \% \quad(100 \%$ $49.00 \%)$ is influenced by other factors not examined. Teacher Performance variability can be explained by the variables of Leadership,

Tabel 20. Anova ${ }^{\mathrm{b}}$ Influence of Leadership, Organizational Climate and Job Satisfaction ANOVA $^{a}$

\begin{tabular}{llccccc}
\hline & Model & Sum of Squares & Df & Mean Square & F & Sig. \\
\hline & Regression & 686,707 & 3 & 228,902 & 16,339 &, $000^{\mathrm{b}}$ \\
1 & Residual & 714,493 & 51 & 14,010 & & \\
Total & 1401,200 & 54 & & & \\
\hline
\end{tabular}

a. Dependent Variable: Teacher Performance

b.Predictors: (Constant), Leadership, Organizational Climate, Job Satisfaction

\section{Multiple Linear Regression Analysis}

Multiple linear regression analysis between the variables of Organizational Climate Leadership and Job Satisfaction on Teacher Performance in the State-Owned High School 1, located in Tanah Jawa, Simalungun Regency, it can be seen from the regression equation, and from the SPSS output obtained the following data.

Tabel 21. Statistical Test Results of Regression Coefficients Influence of Leadership, Organizational Climate and Job Satisfaction on Teacher Performance

\begin{tabular}{|c|c|c|c|c|c|c|}
\hline & \multirow[t]{2}{*}{ Model } & \multicolumn{2}{|c|}{$\begin{array}{l}\text { Unstandardized } \\
\text { Coefficients }\end{array}$} & \multirow{2}{*}{$\begin{array}{c}\begin{array}{c}\text { Standardized } \\
\text { Coefficients }\end{array} \\
\text { Beta }\end{array}$} & \multirow[t]{2}{*}{$\mathrm{T}$} & \multirow[t]{2}{*}{ Sig. } \\
\hline & & $\mathrm{B}$ & Std. Error & & & \\
\hline \multirow{4}{*}{1} & (Constant) & $-2,026$ & 6,899 & &,- 294 & ,770 \\
\hline & Leadership & ,049 & ,149 & ,048 & 3,327 & ,745 \\
\hline & Organizational Climate &, 551 & 127 & ,662 & 4,330 & 000 \\
\hline & Job satisfaction & ,499 & ,118 & ,451 & 4,234 & ,000 \\
\hline
\end{tabular}

a. Dependent Variable: Teacher Performance

The table above can be made a regression equation as follows:

$\mathrm{Y}=-2.026+0.049 \mathrm{X}_{1}+0.551 \mathrm{X}_{2}+0.499 \mathrm{X}_{3}$

The above equation explains that the regression coefficient X1 (Leadership) has a positive value of 0.049 , this shows that the leadership variable has a positive influence on teacher performance in the State-Owned High School 1, located in Tanah Jawa, Simalungun Regency. This shows that if the leadership values are positive, the Teacher Performance will increase by 0.049 .

Regression coefficient X2 (organizational climate) has a negative value of 0.551 , this shows that the organizational climate variable has a positive influence teachers performance in the State-Owned High School 1, located in
Tanah Jawa, Simalungun Regency. This shows that if the organizational climate is negative, the Teacher Performance will increase by 0.551 .

Regression coefficient X3 Job Satisfaction) also has a positive value of 0.499 , this shows that the Job Satisfaction variable has a positive influence on Teacher Performance in the State-Owned High School 1, located in Tanah Jawa, Simalungun Regency. This shows that if the teacher's ability is positive, the teacher's performance will increase by 0.49 . 


\section{CONCLUSION}

Based on the analysis and evaluation of the data above, the conclusions of this study are:

1. Leadership Variables have a positive and significant influence on Teacher Performance in the State-Owned High School 1, located in Tanah Jawa, Simalungun Regency with a value of $\mathrm{t}_{\text {count }}>$ $\mathrm{t}_{\text {table }}(3,327>1,675)$.

2. Organizational Climate Variables have a positive and significant influence on Teacher Performance in the State-Owned High School 1, located in Tanah Jawa, Simalungun Regency c of $\mathrm{t}_{\text {count }}>\mathrm{t}_{\text {table }}(4,430$ $>1,686)$.

3. Job Satisfaction Variables have a positive and significant influence on Teacher Performance in the State-Owned High School 1, located in Tanah Jawa, Simalungun Regency in the State-Owned High School 1, located in Tanah Jawa, Simalungun Regency $t_{\text {count }}>t_{\text {table }}(4,234>$ 1,675).

4. Leadership, Organizational Climate and Job Satisfaction Variables have a positive and significant influence on Teacher Performance in the State-Owned High School 1, located in Tanah Jawa, Simalungun Regency with a value of $\mathrm{t}_{\text {count }}>$ $t_{\text {table }}(16,339>2,783)$.

\section{ACKNOWLEDGEMENT}

On this occasion, the author also expressed his gratitude to all parties who have provided assistance, especially the principal of the participated the State-Owned High School 1, located in Tanah Jawa, Simalungun Regency.

\section{REFERENCES}

Al-Kurdi, O. F., El-Haddadeh, R., \& Eldabi, T. (2020). The role of organisational climate in managing knowledge sharing among academics in higher education. International Journal of Information Management, 50(November 2018), $217-$
227.

https://doi.org/10.1016/j.ijinfomgt.201 9.05 .018

Almaki, S. H., Silong, A. D., Idris, K., \& Abd. Wahat, N. W. (2016). Understanding of the Meaning of Leadership from the Perspective of Muslim Women Academic Leaders. Journal of Educational and Social Research, 6(2), 225-236. https://doi.org/10.5901/jesr.2016.v6n2 p225

Andersson, M., Moen, O., \& Brett, P. O. (2020). The organizational climate for psychological safety: Associations with SMEs' innovation capabilities and innovation performance. Journal of Engineering and Technology Management JET-M, 55(January 2017), 101554. https://doi.org/10.1016/j.jengtecman.20 20.101554

Balyer, A., Teknik, Y., Eğitim, Ü., Bölümü, E. B., Üniversitesi, A., Fakültesi, E., \& Bölümü, E. B. (2017). Organizational Climate At Primary Schools and Its Influences On Teachers Job Satisfaction İlköğretim Okullarında Örgütsel İklim ve $\mathrm{Bu}$ İklimin Öğretmenlerin İş Doyumları Üzerindeki Etkileri. Kastamonu Education Journal, 25(5), 1737-1752.

Baptiste, M. (2019). No Teacher Left Behind: The Impact of Principal Leadership Styles On Teacher Job Satisfaction and Student Success. Journal of International Education \& Leadership, 9(1), 1-11. Retrieved from http://search.ebscohost.com/login.aspx ?direct $=$ true $\&$ Auth Type $=$ shib $\& d b=$ eue $\& A N=135154244 \&$ site $=$ eds-live

Chu, F., Fu, Y., \& Liu, S. (2019). Organization is also a "life form": Organizational-level personality, Job Satisfaction, and Safety Performance of High-Speed Rail Operators.

https://doi.org/10.1016/j.aap.2019.01.0 27

Diriwaechter, P., \& Shvartsman, E. (2018). The Anticipation and Adaptation Effects of Intra- and Interpersonal Wage Changes on Job Satisfaction. Journal of Economic Behavior and Organization, 146, 116-140. 
https://doi.org/10.1016/j.jebo.2017.12. 010

Izzati, U. A. (2017). The Relationships between Vocational High School Teachers Organizational Climate and Innovative Behavior. International Conference on Education Innovation, 173(ICEI 2017), 343-345. Atlantis PresS.

Leraas, H. J., Cox, M. L., Rhodin, K. E., Freischlag, K., Gilmore, B. F., Chang, D., ... Migaly, J. (2019). Medical Student Involvement and Learning Objectives in Morbidity and Mortality Conferences: A National Survey of the Association for Surgical Education's Committee of Clerkship Directors. Journal of Surgical Education, $\quad 00(00), \quad 1-6$. https://doi.org/10.1016/j.jsurg.2019.07. 010

Liu, Y., \& Werblow, J. (2019). The operation of Distributed Leadership and the Relationship with Organizational Commitment and Job Satisfaction of Principals and Teachers: A multi-level Model and Meta-analysis using the 2013 TALIS Data. International Journal of Educational Research, 96(December 2018), 41-55.

https://doi.org/10.1016/j.ijer.2019.05.0 05

Meng, J., \& Berger, B. K. (2019). The Impact of Organizational Culture and Leadership Performance on PR Professionals' job Satisfaction: Testing the Joint Mediating Effects of Engagement and Trust. Public Relations Review, 45(1), 64-75. https://doi.org/10.1016/j.pubrev.2018.1 1.002

Munir, H., \& Iqbal, M. Z. (2018). A Study of Relationship between Leadership Styles of Principals and Job Satisfaction of Teachers in Colleges for Women. Bulletin of Education and Research, 40(2), 65-78.

Okoli, I. E. (2018). Organizational Climate and Job Satisfaction among Academic Staff: Experience from Selected Private Universities in Southeast Nigeria. International Journal of Research in Business Studies and Management, 5(12), 36-48.

Porter, Michael E., and N. N. (2010). "What Is Leadership: The CEO's Role in Large,
Complex Organizations.” (N. Nohria \& R. Khurana, Eds.). Harvard Business Press, 2010.

Pritchard, R. D., \& Karasick, B. W. (1973). The Effects of Organizational Climate on Managerial Job Performance and Job Satisfaction. Organizational Behavior and Human Performance, 9(1), 126-146. https://doi.org/10.1016/00305073(73)90042-1

Suandi, T., Ismail, I. A., \& Othman, Z. (2014). Relationship Between Organizational Climate, Job Stress And Job Performance Officer At State Education Department. International Journal of Education and Literacy Studies, 2(1), 17-28. https://doi.org/10.7575/aiac.ijels.v.2n.1 p.17

Suhendro, D. (2017). Pengaruh Kualitas Sistem, Kualitas Informasi, Kualitas Pelayanan Dan Ekspektasi Kinerja Terhadap Kepuasan Pengguna Dalam Penerapan Sistem Teknologi Informasi Pada Koperasi Di Kota Pematangsiantar. Jurasike (Jurnal Riset Sistem Informasi Dan Teknik Informatika), 1(1), 33-40. https://doi.org/10.30645/jurasik.v1i1.6

Yuh, J., \& Choi, S. (2017). Sources of social support, job satisfaction, and quality of life among childcare Teachers. Social Science Journal, 54(4), 450-457. https://doi.org/10.1016/j.soscij.2017.08. 002 